\title{
Teaching Speaking Online Using Digital Mind Mapping Software (Dmms) and Screen Recording Tool (Srt): A Practical Method
}

\author{
Ismail Anas ${ }^{1,2, *}$, Muhammad Basri ${ }^{2}$, Andi Musdariah ${ }^{1}$, Rosidah Anas ${ }^{3}$ \\ ${ }^{1}$ Politeknik Negeri Ujung Pandang (doctoral student at Universitas Negeri Makassar) \\ ${ }^{2}$ Universitas Negeri Makassar \\ ${ }^{3}$ Universitas Megarezky Makassar \\ *Corresponding author.Email: ismailanas@poliupg.ac.id
}

\begin{abstract}
Teaching English online during the pandemic calls for innovative technological and pedagogical approaches to shape a meaning-making learning practice. Based on Task-Based Language Teaching with Technology, this "how-to" article offers a practical method for integrating Digital Mind Mapping Software (DMMS) with Screen Recording Tools (SRTs) to enhance students' online speaking practice. It provides a step-by-step guide for incorporating CALL technology and pedagogy to provide students with meaningful online speaking practice. First, it gives a brief overview of DMMS and SRTs and how they may help EFL teachers offer online speaking courses. Second, a pedagogical framework for integrating DMMS with SRTs is presented. Third, it includes guidance for developing a TBLT-based instruction for remotely teaching speaking utilizing the DMMS-SRT integrated strategy. Still, it covers three consecutive stages: pre-task, during-task, and post-task activities. In the end, we include a practical approach (an assessment rubric) to evaluating the students-created tasks (e.g., audio and video recordings). This article will contribute to the plethora of CALL pedagogies, TELT approaches, and digital language teacher professional development.
\end{abstract}

Keywords: DMMS, SRT, TBLT-based instruction, teaching speaking, online learning.

\section{INTRODUCTION}

Richards [1], for example, describes several approaches to teaching both receptive (listening) and productive (speaking) skills; however, he didn't give attention to the principles of how to teach them online. Teaching speaking online calls for an innovative CALL-TELT integration to support students' online speaking activities during the pandemic. In most traditional classrooms, EFL teachers might be familiar with some well-known strategies for stimulating the speaking practices such as pair conversation, solo talk, group discussion, etc. However, Work from Home (WFH) and Study from Home ( $\mathrm{SfH}$ ) policies have significantly changed the way teachers teach and interact with their students distantly. Consequently, EFL teachers must quickly adapt to the current mode of e-teaching and elearning [2]. Yet, delivering a virtual speaking course might be daunting for some teachers because they have to find practical approaches to increasing the students' participation in online speaking activities. Given the importance of speaking practices in SLA processes, teaching speaking should allow students to talk and converse with other learners. In other words, Teacher Talking Time (TTT) should be less than Student Talking Time (STT).

To date, the role of digital technologies and their integration in assisting online speaking activities has not attracted much attention from CALL researchers. On the other hand, the current curriculum does not emphasize online speaking course delivery, so the lecturers have little experience, technological skills, and pedagogical knowledge in designing online instructions. To fill these gaps, this article presents the integration of Digital Mind Mapping Software (DMMS) and Screen Recording Tool (SRT) to support the students' online speaking practices. It 
promotes the students' activeness and autonomy in distant learning and offers alternative CALL innovations for language teaching and learning.

The DMMS-SRT integrated strategy will contribute to CALL pedagogy, TELT approaches, and digital language teacher professional development. In addition, the purpose of this article is to address the lack of CALL innovations in digital language learning.

\section{LITERATURE REVIEW}

\subsection{Digital Mind Mapping Software (DMMS)}

Mind-mapping is a spider-like diagram that depicts topic organization as representations of thoughts, words, and images [3], [4]. It is a visualspatial technique for expanding a primary notion into a larger area of concept organization. DMMS is a potent imaginative practice for forming ideas and connections often produced on a blank computer page. It has its unique features for drawing, diagramming, and charting ideas or information [5]. It can also help improve brainstorming and ideagenerating processes [6]. The concept is a generic technique that may be utilized in any discipline depending on how we modify it to meet the goal lesson. It is just a teaching resource with numerous possible uses in every field of study [7]. For example, EFL writing may improve students' writing performance by developing the content paragraph structure and writing length [8].

Mind mapping strategy is similar to the concept and argument mapping [9]. It affects speaking accuracy [10], improves the EFL speaking fluency [11], and triggers the EFL spontaneous speaking [12]. Mind mapping is the umbrella term for concept and argument mapping, which supports the conceptualization and representation of ideas in an organized and hierarchical diagram. It is typically used to generate broad themes. In contrast, concept mapping is used to develop particular concerns (e.g., telling a process, a business plan, or a fundamental concept of something). In the EFL context, mind mapping can be adopted as a pedagogical tool in language teaching and learning settings [13]. It has the ability to increase the effectiveness of the students' questions. [14].

There are many types of DMMS available on the internet in both free and professional versions. A brief description of some DMMS is given below:
1. XMind: this software is a DMMS developed by XMind.Ltd (https://www.xmind.net/). It runs on desktop computers (Windows, macOS, and Linux), smartphones (Android or iOS), and web browsers (Chrome, IE, Opera, etc.). The storage system also connects to Google Drive, Dropbox, and Microsoft OneDrive. It is one of the graphic engines that helps to visualize and stylize the idea development. To use this software, the users need to register to gain both free and professional access.

2. MindMeister: It is an online mind mapping tool that allows you to visually capture, develop, and share ideas (https://www.mindmeister.com). It is a mind map editor for brainstorming, notekeeping, project planning, and other creative tasks. Interestingly, it is entirely web-based, so there is no downloading or upgrading required. Users can always view their mind maps directly inside the web browser, whether you're using Windows, Mac OS, or Linux. To use the service, the users will need to register either using your Google or Facebook account.

3. Bubbl.us: Based in Houston, Texas, Bubbl.us has been a solid and growing mind mapping tool since 2006 (https://bubbl.us/). It is an easy way to organize ideas visually with a user-friendly interface and interactive collaboration feature. It has been used in a teaching writing course to promote mobile-based technology in developing writing themes and sub-themes[15].

Nowadays, there have been numerous digital mind mapping tools the users can choose from on the internet. The tools above are examples of DMMS generated by the search engine among the many other services from different companies or developers (e.g., Mindmap, TheBrain, Venngage, Edraw Mindmaster, Coggle, SimpleMind, etc.).

\subsection{Screen Recording Tool}

Screen Recording Tool (henceforth SRT) is a computer-based app used to capture and record screen activities and save them into multimedia format (MP4). Screen recording is also known as screencasting or video screen capture [16]. Screencast-O-Matic is one of the SRTs used to create video recordings with or without audio of a real-time action or content on a computer screen [17]. For example, [18] found that it improves the students' verbal-linguistic intelligence. Screencasting is commonly used to create a learning media in assisting EFL teachers in delivering English courses 
online. Alternatively, teachers can choose other applications such as Bandicam, OBS studio, iTop, etc. For example, [19] utilized Bandicam in developing flipped classroom strategy in teaching reading. They found that its utilization promotes the students' activeness and awareness of using digital technology.

Screencast-O-Matic and Bandicam are more popular and accessible for the students than any other application on the internet. They capture and record their material presentations and share them with the students. On the other hand, [19] utilized it to give feedback to their students. With this in mind, the students will also be able to capture and record their talks and then share them with others. Interestingly, the students learn how to speak and use digital technology to create a multimedia product as their learning output.

\subsection{The Teaching of Speaking}

There are at least three phases to learning to speak: (1) conceptualization, (2) formulation, and (3) articulation [20]. However, before the speakers can create and express their message, they must first construct a concept of what they wish to say [21]. Given the importance of conceptualization skills in enhancing speaking ability, DMMS as a pedagogical tool for teaching speaking is meant to give a new nuance of learning that incorporates the stages of conception, formulation, and articulation of ideas in developing speaking abilities. On the other hand, EFL teachers should have been taught and equipped with pedagogical expertise to engage their students in oral English activities [22]. In response to critical pedagogy, EFL teachers should employ welldeveloped techniques and pedagogical approaches to engage and activate students' learning [23]. However, teaching should be creative, exploratory, and strategic [24].

\section{DMMS-SRT INTEGRATED FRAMEWORK}

This article aims to bring DMMS and SRT together using the EPCR (explore, practice, create, and reflect) framework (see figure 1). This framework is orchestrated under the umbrella of the TBLT lens, where learners are assigned to explore, practice, create and reflect on DMMS-SRT integrated learning.

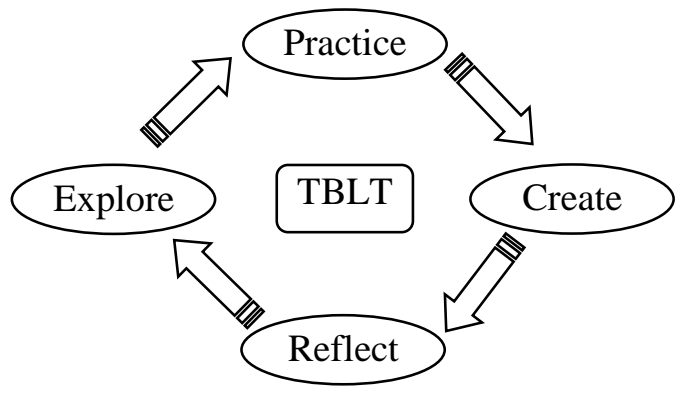

Figure 1. EPCR Framework

The EPCR framework describes how TBLT mediates the integration of DMMS and SRT in supporting the students' online speaking practices.

Explore: In this stage, the students are encouraged to explore the selected DMMS and SRT with or without tutorials from the lecturers. Regarding the DMMS, the students must explore how to search, download, install, and use the software to produce a mind map diagram of their ideas. They can try several DMMS and SRT as they start to explore. The ability to use the tools effectively depends on the students' digital literacy skills or, in other words, digital competencies.

Practice: There is a saying, practice makes perfect, which means the more you practice, the more you learn. Using the student-created mind-mapping diagrams, they then practice reading the map several times. It aims to familiarize themselves with the topics and sub-topics in the chart. They learn to present the diagrams which they have created using English. In addition, they can collaborate with others in case they have difficulties in preparing their talks.

Create: Once they have adequate knowledge of using the DMMS and SRT and practiced describing the map, they can continue to create a screencast video using the SRT. This phase is the video production stage, where the students create videos by screencasting the computer screen displaying the created mind-mapping diagram and the presenters' video. The result of this activity is a multimedia file (MP4) which they can share with others.

Reflect: Digital reflection is the ability to reflect on the digital technologies that we have used. It aims to evaluate its effectiveness and failures for future development. The students with adequate knowledge and ability to do high-level reflection tend to perform better in any technology-related tasks assigned to them. However, using the framework should consider the learning context, students' digital literacy skills, the pedagogical affordances of DMMS-SRT integrated learning. 


\section{DEVELOPING A TBLT-BASED INSTRUCTION}

In this section, we present a step-by-step guide to developing a TBLT-based instruction using the EPCR framework. Grounded in Ellis' TBLT framework [25], [26], we set the following steps to create online TBLT-based instructions.

Table 1. TBLT-based instruction development

\begin{tabular}{ll}
\hline Pre-task & 1. Preparation (e.g., tools, target \\
language, speaking topic, etc.) \\
2. Exploration (e.g., online workshops \\
on using DMMS and SRT, \\
developing speaking themes and sub- \\
themes, etc.) \\
3. Define the speaking topic (e.g., \\
talking about family, likes \& dislikes, \\
or advanced subjects such as \\
business plan, marketing plan, etc.) \\
\hline 1. Ask the students to create a mind- \\
mapping diagram (using DMMS) \\
based on the chosen topic. You can \\
either check or monitor their progress \\
during this activity (e.g., share the \\
images in WhatsApp group) \\
2. Practice: ask the students to practice \\
reading and describing the map they \\
have created. \\
3. Create: ask the students to screencast \\
their videos (using SRT) describing \\
the topic based on the created map. \\
4. Ask the students to share the videos \\
on designated online platforms \\
1. Ask the students to reflect on their \\
video tasks (e.g., online self- \\
reflection, written reflection, etc.) \\
2. Discuss the results of the reflection \\
with the students for feedback or \\
suggestions
\end{tabular}

The quality of the task instructions depends on the teachers' technological and pedagogical knowledge and digital literacy skills. The higher the teachers' digital knowledge and literacy skills, the better they will perform and design the TBLT-based instructions. If the teachers are creative and innovative, they can create even more exciting activities for their students and engage them in the virtual learning environment.

\section{ASSESSMENT RUBRIC}

The output of this activity is video documents created by students in the form of a multimedia file (MP4). To assess the students' speaking performance, we adopt the following speaking assessment rubric [27]:

Table 2. Speaking Assessment rubric [27]

\begin{tabular}{ll}
\hline \multicolumn{1}{c}{ Criteria } & \multicolumn{1}{c}{ Description } \\
\hline Grammar & $\begin{array}{l}\text { The ability of the speakers to } \\
\text { speak grammatically and } \\
\text { accurately }\end{array}$ \\
\hline Vocabulary & $\begin{array}{l}\text { The speakers can use a wide } \\
\text { range and accurate vocabulary }\end{array}$ \\
\hline Pronunciation & $\begin{array}{l}\text { The speakers can pronounce the } \\
\text { words accurately based on stress, } \\
\text { intonation, rhythm, linking, and } \\
\text { phonemic distinctions. }\end{array}$ \\
\hline Fluency & $\begin{array}{l}\text { It relates to the speakers' speed } \\
\text { of talking as well as their } \\
\text { hesitation before and while } \\
\text { speaking. }\end{array}$ \\
\hline $\begin{array}{l}\text { Conversation } \\
\text { skills }\end{array}$ & $\begin{array}{l}\text { It relates to the speakers' ability } \\
\text { to develop the topic, including } \\
\text { turn-taking and control over } \\
\text { issues. It also deals with } \\
\text { cohesion and conversation } \\
\text { maintenance. }\end{array}$ \\
\hline Socio-linguistic & $\begin{array}{l}\text { It relates to using cultural } \\
\text { references, formal/ informal } \\
\text { language, and persuasive skills. }\end{array}$ \\
\hline Content & $\begin{array}{l}\text { The relevance of the topic with } \\
\text { the contents of the talk and the } \\
\text { coherence of the arguments. }\end{array}$ \\
\hline $\begin{array}{l}\text { Eye contact, hand gestures, } \\
\text { expressions, body movement, } \\
\text { etc. }\end{array}$ \\
\hline
\end{tabular}

Given that the accuracy of the speaking skills measurement still relies on the raters' subjectivity, we suggest the EFL teachers (who mostly become the raters) explore every criterion of the rubric to perform a balanced and fair assessment. For example, the raters will need to know what it means to be cohesive, coherent, and clear in a speaking discourse. In addition, the gradation for the measurement of each criterion falls between excellent (marked 4) and poor (marked 1) speaking performance. For example, adopting a psychometric analysis of the Likert scale can be considered. 


\section{CONCLUSION}

Integrating DMMS and SRT to support the students' online speaking practice calls for discussions and debates in the critical CALL pedagogy and online learning instruction development. It also corresponds to the theories of TBLT with technology [28], in which DMMS-SRT integrated learning can be an alternative methodology in supporting digital language learning development. On the other hand, it also has implications for the digital language teacher's professional development and students' digital literacy skills. In other words, exploring the teachers' and students' digital competencies is necessary before employing the TBLT-based instruction with technology.

\section{ACKNOWLEDGMENTS}

We would like to thank Unit Jurnal dan Publikasi Politeknik Negeri Ujung Pandang for funding the conference registration and publication.

\section{REFERENCES}

[1] J. C. Richards, Teaching listening and speaking: from theory to practice. Cambridge, UK: Cambridge University Press, 2008.

[2] V. P. H. Pham and T. N. Da Vo, "CALL in Asia During Covid-19 and Models of E-Learning," Proc. 17th Int. Conf. Asia Assoc. Comput. Lang. Learn. (AsiaCALL 2021), vol. 533, pp. 1-10, 2021, doi: 10.2991/assehr.k.210226.001.

[3] T. Buzan and B. Buzan, The mind map book: how to use radiant thinking to maximize your brain's untapped potential. New York and London: Penguin Group, 1994.

[4] T. Buzan and S. Abbott, The ultimate book of mind maps: unlock your creativity, boost your memory, change your life. Thorsons, 2006.

[5] M. Myre, "The best mind mapping software in 2021," Zapier, 2021. https://zapier.com/blog/ best-mind-mapping-software/ (accessed Aug. 06, 2021).

[6] H. Lin and H. Fast, "Digital mind mapping: innovations for real-time collaborative thinking," in Conference on Human Factors in Computing Systems - Proceedings, 2011, pp. 2137-2142, doi: 10.1145/1979742.1979910.

[7] S. Edwards and N. Cooper, "Mind mapping as a teaching resource," Clin. Teach., vol. 7, no. 4, pp. 236-239, 2010, doi: 10.1111/j.1743498X.2010.00395.x.

[8] S. S. F. Bukhari, "Mind Mapping Techniques to Enhance EFL Writing Skill,” Int. J. Linguist. Commun., vol. 4, no. 1, pp. 58-77, 2016, doi: 10.15640/ijlc.v4n1a7.

[9] M. Davies, “Concept mapping, mind mapping and argument mapping: What are the differences and do they matter?," High. Educ., vol. 62, no. 3, pp. 279-301, 2011, doi: 10.1007/s10734-010-9387-6.

[10] A. Kazemi and A. Moradi, "The influence of concept mapping and rehearsal on speaking accuracy and complexity," Cogent Arts Humanit., vol. 6, no. 1, pp. 1-21, 2019.

[11] B. Ghonsooly and A. Hosienpour, "The Effect of Concept Mapping on EFL Speaking Fluency Archive,” Iran. J. Appl. Linguist., vol. 12, no. 1, pp. 87-114, 2009.

[12] H. Khoshsima, A. Saed, and A. Hakimzadeh, "Concept Mapping Strategy: A Strategic Alternative to the Matter of Spontaneous Speaking of Iranian Intermediate EFL Learners," Int. J. Lang. Linguist., vol. 4, no. 1, pp. 1-8, 2016, doi: 10.11648/j.ij1l.20160401.11.

[13] L. Kadagidze, "Mind Mapping as a Teaching Tool in Higher Education Language Learning Settings," in Kultura i Edukacja, vol. 4, no. 114 , J. Piechowiak-Lamparska, Ed. Torun: Kultura i Edukacja, 2016, pp. 78-88.

[14] H. Stokhof, B. de Vries, T. Bastiaens, and R. Martens, "Using Mind Maps to Make Student Questioning Effective: Learning Outcomes of a Principle-Based Scenario for Teacher Guidance," Res. Sci. Educ., vol. 50, no. 1, pp. 203-225, 2020, doi: 10.1007/s11165-017-96863.

[15] R. Abd Karim, M. H. Mohd Tahir, and A. H. Mohd Adnan, "Bubbl.us: a digital mindmapping tool to promote a mobile-based technology approach in writing courses," in Emerging Perspectives and Trends in Innovative Technology for Quality Education 4.0, U. Kusmawan, S. Aisyah, I. Rokhiyah, Andayani, D. R. Jovanka, and D. Sukmayadi, Eds. London, UK: Taylor \& Francis, 2020, pp. 231-235.

[16] A. Charlton and D. Kenwright, "Getting started 
with screen recording," 2020, doi: 10.24135/pjtel.v2i1.33.

[17] A. Glusker, "Screencast-o-Matic (a resource review)," J. Med. Libr. Assoc., vol. 109, no. 2, pp. 355-358, 2021.

[18] C. Hasanudin and A. Fitrianingsih, "The Implementation of Flipped Classroom using Screencast-O-Matic to Improve Students' Verbal Linguistic Intelligence,” Int. J. Eng. Technol., vol. 7, no. 4.15, pp. 435-439, 2018, doi: 10.14419/ijet.v7i4.15.23602.

[19] D. Cheng and M. Li, "Screencast Video Feedback in Online TESOL Classes," Comput. Compos., vol. 58, p. 102612, 2020, doi: 10.1016/j.compcom.2020.102612.

[20] S. Thornbury, How to teach speaking. Harlow: Pearson, Longman, 2007.

[21] E. R. Felker, H. E. Klockmann, and N. H. De Jong, "How conceptualizing influences fluency in first and second language speech production," Appl. Psycholinguist., vol. 40, pp. 111-136, 2019, doi: 10.1017/S0142716418000474.

[22] Z. Chen and C. Goh, "Teaching oral English in higher education: Challenges to EFL teachers," Teach. High. Educ., vol. 16, no. 3, pp. 333-345, 2011.

[23] M. Alexandrzak, "Problems and challenges in teaching and learning speaking at advanced level," Glottodidactica, vol. 37, pp. 37-48, 2011.

[24] J. L. Rinkevich, "Creative Teaching: Why it Matters and Where to Begin," Clear. House A J. Educ. Strateg. Issues Ideas, vol. 84, no. 5, pp. 219-223, 2011, doi: 10.1080/00098655.2011.575416.

[25] R. Ellis, "The Methodology of Task-Based Teaching," in The Asian EFL Journal Quarterly, 2006, pp. 19-45.

[26] R. Ellis, Task-Based Language Learning and Teaching. Oxford: Oxford University Press, 2003.

[27] B. Knight, "Assessing speaking skills: A workshop for teacher development," ELT J., vol. 46, no. 3, pp. 294-302, 1992, doi: 10.1093/elt/46.3.294.
[28] M. Thomas and H. Reinders, Task-Based Language Learning and Teaching with Technology. London, UK: Continuum, 2010. 